\title{
PENGARUH PENAMBAHAN ABU AMPAS TEBU \& ARANG BATOK KELAPA TERHADAP STABILISASI DAYA DUKUNG \\ TANAH
}

\author{
Alfinda Threvanian Putri ${ }^{*}$, Sigit Winarto ${ }^{2}$, Ahmad Ridwan ${ }^{3}$ \\ ${ }^{1,2,3}$ Fakultas Teknik, UniversitasKadiri \\ email : *1alfinda15512945@gmail.com, ${ }^{2}$ sigit.winarto@unik-kadiri.ac.id, \\ 3ahmad_ridwan@unik-kadiri.ac.id.
}

\begin{abstract}
Each region has soil conditions that are not the same as other regions, some have good soil carrying capacity, and some are bad. The soil stabilization process involves mixing the soil with other soils to obtain the desired gradation. Stabilization is carried out if the land at the project site does not meet the requirements when used for engineering certain buildings. In the study of clay soil tested came from Jampi Hamlet of Ngentrong Village, Karangan District, Trenggalek Regency - East Java Province, the method of a mixture of bagasse ash and coconut shell charcoal consisted of 4 variations, each using a different mixture content ie 0\%, 7\%, 10\%, and 15\%, This research was conducted at the Civil Engineering Laboratory of Kadiri University. The results of the study showed that the addition of a mixture of bagasse ash and coconut shell charcoal affected soil stability. At a percentage of 15\%, it produces a liquid limit of $39 \%$, a plastic limit of $28.38 \%$, a plastic index of $10.62 \%$, the addition is able to improve soil properties, given that the original soil structure has a higher level of plasticity.
\end{abstract}

Keywords : Clay, Stabilization, Sugar Crane Ash, Coconut Charcoal.

\begin{abstract}
Abstrak
Setiap daerah memiliki kondisi tanah yang tidak sama dengan daerah lainnya, ada yang mempunyai kondisi daya dukung tanah yang baik dan ada pula yang buruk. Proses stabilisasi tanah meliputi pencampuran tanah dengan tanah lain untuk memperoleh gradasi yang diinginkan. Stabilisasi dilakukan bila tanah di lokasi proyek tidak memenuhi syarat bila digunakan untuk rekayasa bangunan tertentu. Pada penelitian tanah lempung yang diuji ini berasal dari Dusun Jampi Desa Ngentrong Kec.Karangan Kab.Trenggalek - provinsi Jawa Timur, metode campuran abu ampas tebu dan arang batok kelapa terdiri dari 4 variasi, masing-masing mengggunakan kadar campuran yang berbeda yaitu $0 \%, 7 \%, 10 \%$, dan 15\%, Penelitian ini dilaksanakan di Laboratorium Teknik Sipil Universitas Kadiri. Hasil uji penelitian menunjukkan bahwa penambahan campuran abu ampas tebu dan arang batok kelapa berpengaruh terhadap stabilitas tanah. Pada presentase $15 \%$ mengahasilkan batas cair 39\%, batas plastis $28,38 \%$, indeks plastis $10,62 \%$, penambahan tersebut mampu memperbaiki sifat tanah, mengingat bahwa struktur tanah asli memiliki tingkat keplastisan yang lebih tinggi.
\end{abstract}

Kata Kunci : Lempung, Stabilisasi, Abu Ampas Tebu, Arang Kelapa. 


\section{PENDAHULUAN}

Tanah memiliki peranan penting dalam bidang konstruksi sebagai dasar pondasi [1]. Tanah sendiri terdiri dari agregat atau butiran mineral padat yang tidak tersementasi satu sama lain [2][3]. Suatu konstruksi akan berdiri kokoh apabila dibangun diatas tanah dengan daya dukung yang memenuhi syarat [4].Daya dukung lapisan tanah tergantung pada kepadatan tanah itu sendiri [5][6]. Di Indonesia tidak banyak tanah yang memiliki nilai CBR tinggi atau biasa disebut tanah padat. Tanah yang memiliki daya dukung tanah rendah pada kondisi muka air yang tinggi disebut tanah lempung[7][8]. Penelitian terhadap tanah lempung perlu dilakukan untuk mencari alternative terbaik guna meningkatkan kualitas tanah tersebut[9].

Stabilisasi tanah merupakan cara untuk memperbaiki sifat teknis tanah [10]. Proses stabilisasi meliputi pencampuran tanah dengan bahan lain untuk memperoleh gradasi yang diinginkan [11]. Stabilisasi perlu dilakuakan bila tanah di lokasi proyek tidak memenuhi syarat yang ditentukan [12][13]. Tujuan dari penelitian ini yaitu untuk mengetahui seberapa besar pengaruh campuran abu ampas tebu dan arang kelapa dengan kadar 0\%,7\% (5:2), $10 \%$ (8:2), dan $15 \%$ (13:2) terhadap stabilisasi daya dukung tanah[14] Abu ampas tebu dipilih karena memiliki sifat lepas sehingga mampu mengurangi kohesi tanah lempung [15], sedangkan pada penelitian sebelumnya arang batok kelapa mampu mereduksi indeks plastis tanah, [16].

\section{METODE PENELITIAN}

\subsection{Pengujian.}

Penelitian ini dilakukan di Laboratorium Teknik Sipil Universitas Kadiri Sampel yang digunakan merupakan tanah lempung $M I X$ bahan tambah abu sekam padi dan arang batok kelapa dengan kadar $0 \%, 7 \%(5: 2), 10 \%(8: 2)$, dan $15 \%(13: 2)$. Penelitian sebelumnya telah membahas mengenai stabilitas daya dukung tanah terhadap tanah lempung, akan tetapi tidak banyak penelitian yang membahas mengenai pengaruh penggunaan arang batok kelapa dan ampas tebu terhadap stabilisasi tanah, [17][18][19].

\subsection{Metode Pengumpulan Data.}

Metode yang digunakan dalam penyusunan penelitian ini [20][21][22][23] adalah sebagai berikut :

A. Study literatur.

B. Metode observasi dan pengumpulan data teknis yaitu dengan mengumpulkan data-data tanah pada lokasi penelitian guna sampling dan kondisi sekitar dilapangan.

C. Persiapan bahan abu ampas tebu dan arang batok kelapa yang akan dipergunakan sebagai formula penelitian. 


\subsection{Alur Penelitian.}

Penelitian ini terdiri dari 3 pengujian yaitu pengujian kadar air, pengujian gradasi butir tanah dan batas konsistensi tanah (batas cair, plastisitas, dan kepadatan tanah), dengan langkah pengujian dengan sebagai berikut :

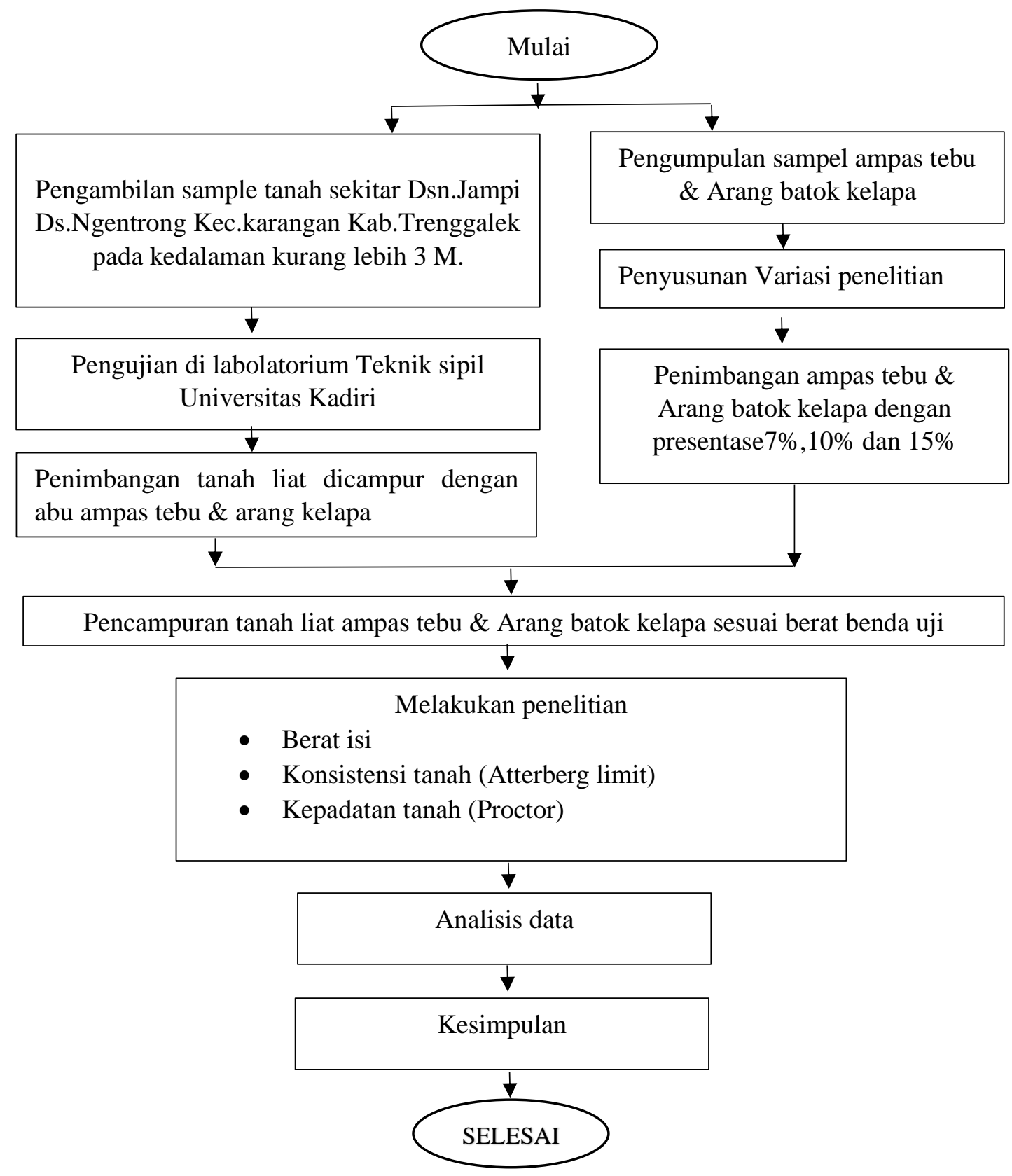

Sumber : Alur Penelitian.

Gambar 1. Diagram Alur Pelaksanaan Penelitian, 


\section{HASIL DAN PEMBAHASAN}

\subsection{Pengujian Karakteristik Tanah.}

Hasil pengujian kadar air (water content) berat tanah asli pada 3 sampel container menunjukan sampel pertama 159 gr, sampel kedua 161 gr,sampel ketiga 161 gr. Berat tanah kering container pada sampel pertama $67 \mathrm{gr}$, sampel kedua $67 \mathrm{gr}$, dan sampel ketiga $67 \mathrm{gr}$, berat air pada container sampel pertama 92 gr, sampel kedua 94 gr dan sampel ketiga 94 gr, kadar air tanah asli sampel pertama 57,86 gr, sampel kedua 58,39 gr dan sampel ketiga 58,39. Volume tanah asli pada container yaitu $226 \mathrm{gr} / \mathrm{cm}^{3}$ volume tanah kering $25,28 \mathrm{gr} / \mathrm{cm}^{3}$ volume pori $200,72 \mathrm{gr} / \mathrm{cm}^{3}$ angka pori 7,93 dan nilai untuk porositas 0,88 .

\subsection{Hasil Uji Batas Konsistensi Tanah.}

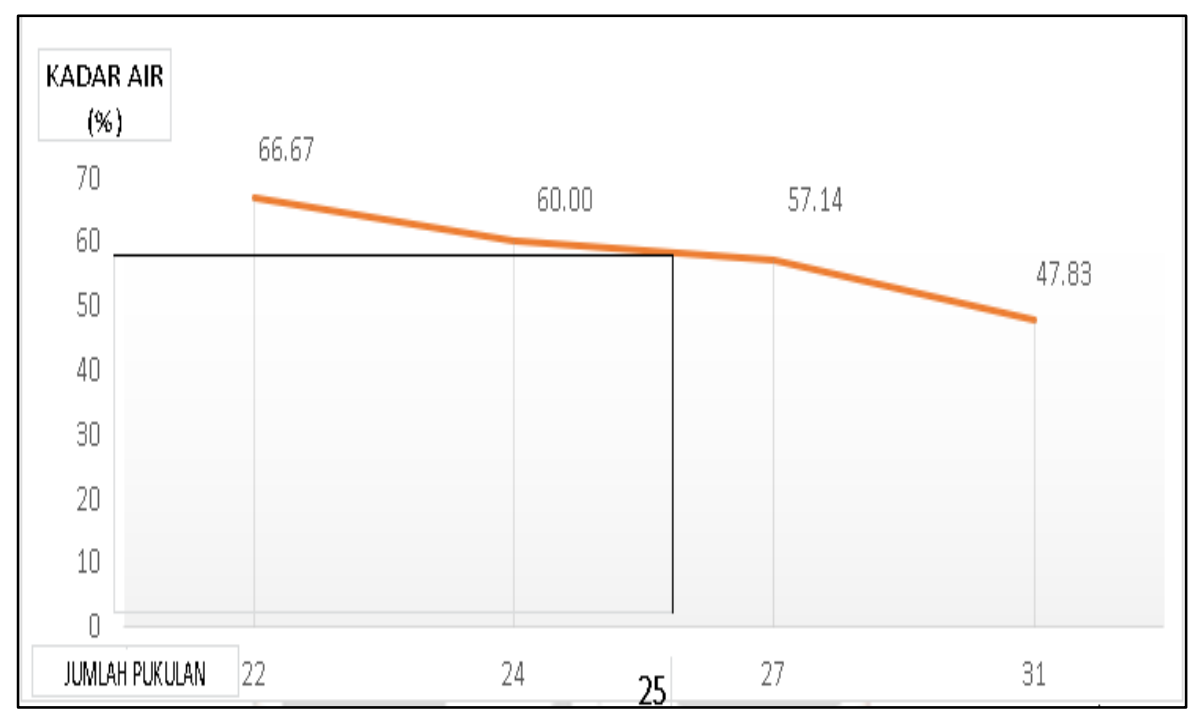

Sumber : Hasil Grafik Uji Liquid Limit di Laboratorium Universitas

Kadiri.

Gambar 2. Liquid Limit Mix 0\% Abu Ampas Tebu dan Abu Batok Kelapa, Sebesar 58\%.

Pada Gambar 2. tentang pengaruh stabilisasi daya dukung tanah pada Liquid Limit $0 \%$ abu ampas tebu dan abu batok kelapa 58\% menunjukan kadar air dengan jumlah bervariatif. Pada 22 pukulan kadar air menunjukan 70\% jumlah pukulan 24 menunjukan 60\% jumlah pukulan 27 menunjukkan 57.14\% jumlah pukulan 31 menunjukkan 47,83\%. Pada Gambar 3. dibawah ini merupakan nilai Liquid Limit 7\% abu ampas tebu dan arang batok kelapa sebesar $50 \%$ pada kadar 50 dengan jumlah pukulan 24. 


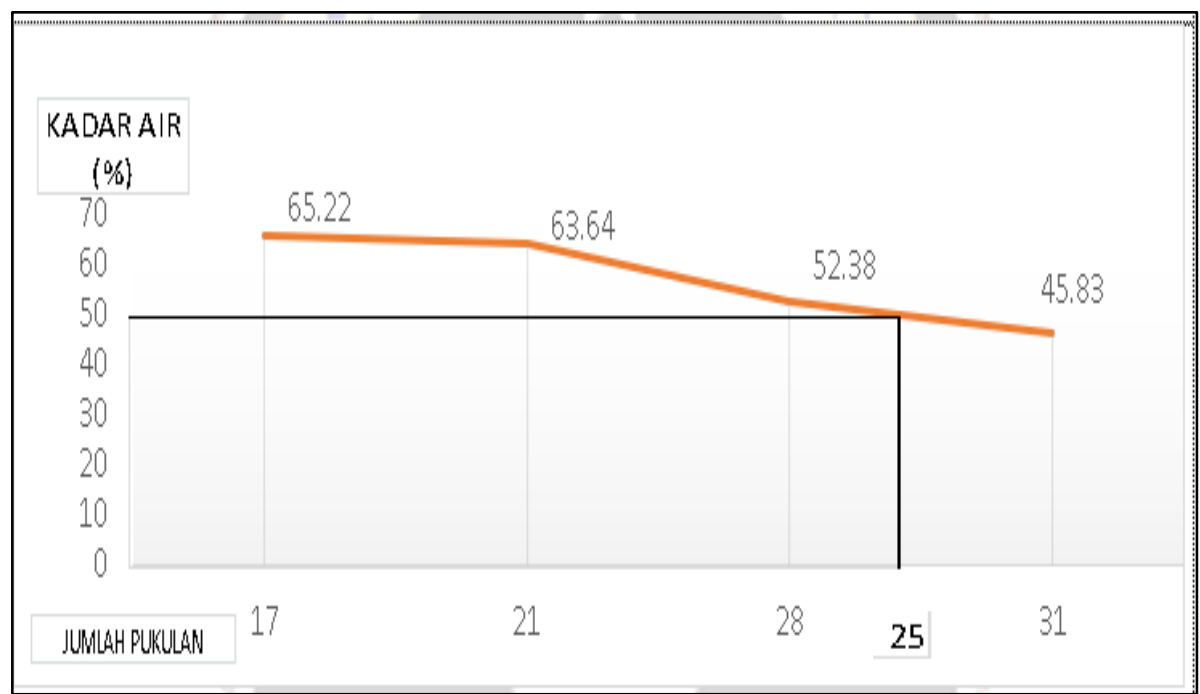

Sumber : Hasil Grafik Uji Liquid Limit di Laboratorium Universitas Kadiri.

Gambar 3. Liquid Limit Mix 7\% Abu Ampas Tebu \& Abu Batok, Sebesar 50\%.

Pada Gambar 4. dibawah ini menunjukkan nilai liquid limit sebesar $10 \%$ abu ampas tebu dan arang batok kelapa sebesar 49\% pada kadar 49 dengan jumlah pukulan 25 .

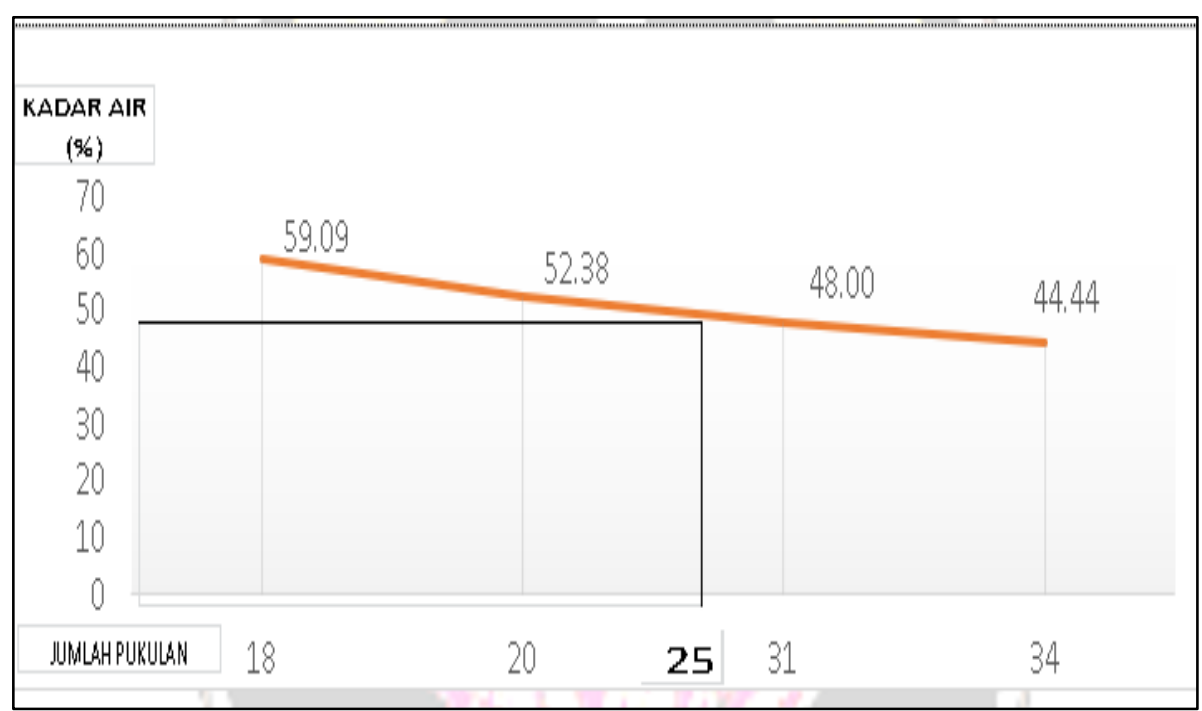

Sumber : Hasil Grafik Uji Liquid Limit di Laboratorium Universitas Kadiri.

Gambar 4. Liquid Limit Mix 10\% Abu ampas Tebu \& Abu Batok Sebesar 49\%. 
Pada Gambar 5. dibawah ini merupakan hasil Liquid Limit sebesar $39 \%$ kadar air $39 \%$ dengan jumlah pukulan 26.

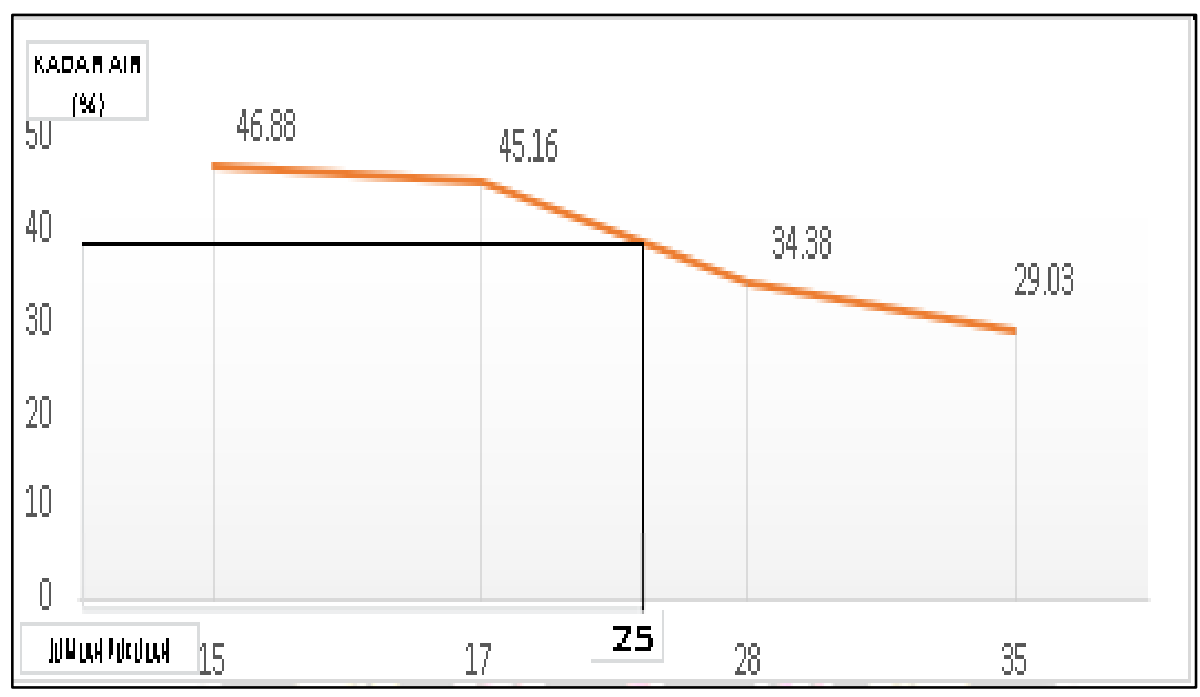

Sumber : Hasil Grafik Uji Liquid Limit di Laboratorium Universitas Kadiri.

Gambar 5. Liquid Limit Mix 15\% Abu Ampas Tebu \&Abu Batok Sebesar 39\%.

Berikut hasil Data Batas Konsistensi Abu Ampas Tebu dan Arang Kelapa : Hasil batas konsistensi Abu Ampas Tebu \& Arang kelapa menunjukan pada nilai 7 \% nilai Liquid Limit 50 $\%$, Plastic Limit $26.30 \%$, Index Plastix $23.70 \%$ sedangkan kadar abu ampas pada nilai $10 \%$ liquid limit $49 \%$, Plastic Limit 29.75\%, Index Plastic 19.25\%. Dan untuk kadar $15 \%$ Abu ampas Liquid Limit 39\%, Plastic Limit 28.38 index Plastic 10.62\%.

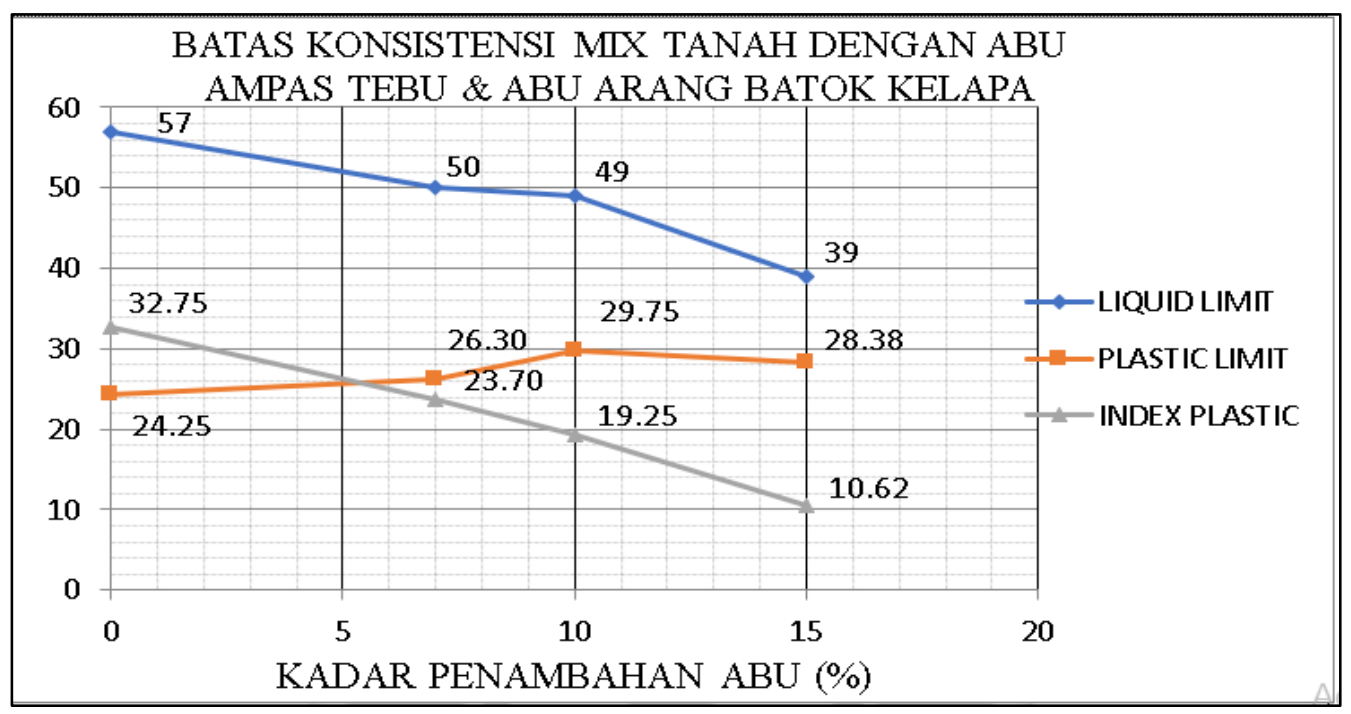

Sumber : Hasil Analisis Uji Batas Konsistensi Keseluruhan Benda Uji Mix.

Gambar 6. Grafik Batas Konsistensi. 


\subsection{Hasil Uji Pemadatan}

Pada Tabel 1. dibawah ini menampilan data hasil data uji proctor abu ampas tebu dan arang kelapa, dapat dilihat sebagai berikut :

Tabel 1. Uji Proctor Mix Tanah Dengan Abu Ampas Tebu Dan Abu Arang Kelapa

\begin{tabular}{|c|c|c|c|c|c|}
\hline \multirow{10}{*}{$\begin{array}{c}\text { Hasil Uji Proctor Mix } \\
\text { Tanah dengan 0\% } \\
\text { Abu Ampas Tebu } \\
\text { Dan Abu Arang } \\
\text { Kelapa }\end{array}$} & BERAT UJI & S. 1 & S. 2 & S.3 & S. 4 \\
\hline & - Berat Cetakan & 4502 & 4502 & 4502 & 4502 \\
\hline & - Berat Tanah Basah + Cetakan & 6242 & 6304 & 6278 & 6273 \\
\hline & - Berat Tanah Basah (W) & 1740 & 1802 & 1776 & 1771 \\
\hline & - Berat Tanah Kering Oven (Ws) & 1075 & 1096 & 1290 & 1222 \\
\hline & - Berat Air $(\mathrm{Ww})=\mathrm{W}-\mathrm{Ws}$ & 665 & 706 & 486 & 549 \\
\hline & - $(\mathrm{Wc})=\mathrm{Ww} / \mathrm{Ws} * 100(\%)$ & 61.86 & 64.42 & 37.67 & 44.93 \\
\hline & - Isi Cetakan $(\mathrm{V})=\Pi \cdot \mathrm{R}^{2} . \mathrm{T}$ & 188.28 & 188.28 & 188.28 & 188.28 \\
\hline & - Berat Volume (Ysat) = W/V & 9.24 & 9.57 & 9.43 & 9.41 \\
\hline & - Berat Volume Kering $(\mathrm{Vd})=\mathrm{Ws} / \mathrm{V}$ & 5.71 & 5.82 & 6.85 & 6.49 \\
\hline \multirow{9}{*}{$\begin{array}{c}\text { Hasil Uji Proctor Mix } \\
\text { Tanah dengan 7\% } \\
\text { Abu Ampas Tebu } \\
\text { Dan Abu Arang } \\
\text { Kelapa }\end{array}$} & - Berat Cetakan & 4502 & 4502 & 4502 & 4502 \\
\hline & - Berat Tanah Basah + Cetakan & 6002 & 6114 & 6202 & 6268 \\
\hline & - Berat Tanah Basah (W) & 1500 & 1612 & 1700 & 1766 \\
\hline & - Berat Tanah Kering Oven (Ws) & 1346 & 1458 & 1522 & 1599 \\
\hline & - Berat Air $(\mathrm{Ww})=\mathrm{W}-\mathrm{Ws}$ & 154 & 154 & 178 & 167 \\
\hline & - $(\mathrm{Wc})=\mathrm{Ww} / \mathrm{Ws} * 100(\%)$ & 11.44 & 10.56 & 11.70 & 10.44 \\
\hline & - Isi Cetakan $(\mathrm{V})=\Pi \cdot \mathrm{R}^{2} . \mathrm{T}$ & 188.28 & 188.28 & 188.28 & 188.28 \\
\hline & - Berat Volume (Ysat) $=\mathrm{W} / \mathrm{V}$ & 7.97 & 8.56 & 9.03 & 9.38 \\
\hline & - Berat Volume Kering $(\mathrm{Vd})=\mathrm{Ws} / \mathrm{V}$ & 7.15 & 7.74 & 8.08 & 8.49 \\
\hline \multirow{9}{*}{$\begin{array}{c}\text { Hasil Uji Proctor Mix } \\
\text { Tanah dengan } 10 \% \\
\text { Abu Ampas Tebu } \\
\text { Dan Abu Arang } \\
\text { Kelapa }\end{array}$} & - Berat Cetakan & 4502 & 4502 & 4502 & 4502 \\
\hline & - Berat Tanah Basah + Cetakan & 6062 & 6061 & 6141 & 6151 \\
\hline & - Berat Tanah Basah (W) & 1560 & 1559 & 1639 & 1649 \\
\hline & - Berat Tanah Kering Oven (Ws) & 1344 & 1538 & 1569 & 1458 \\
\hline & - Berat Air $(\mathrm{Ww})=\mathrm{W}-\mathrm{Ws}$ & 216 & 21 & 70 & 191 \\
\hline & - $(\mathrm{Wc})=\mathrm{Ww} / \mathrm{Ws} * 100(\%)$ & 16.07 & 1.37 & 4.46 & 13.10 \\
\hline & - Isi Cetakan $(\mathrm{V})=\Pi \cdot \mathrm{R}^{2} . \mathrm{T}$ & 188.28 & 188.28 & 188.28 & 188.28 \\
\hline & - Berat Volume $(\mathrm{Y}$ sat $)=\mathrm{W} / \mathrm{V}$ & 8.29 & 8.28 & 8.71 & 8.76 \\
\hline & - Berat Volume Kering $(\mathrm{Vd})=\mathrm{Ws} / \mathrm{V}$ & 7.14 & 8.17 & 8.33 & 7.74 \\
\hline \multirow{9}{*}{$\begin{array}{c}\text { Hasil Uji Proctor Mix } \\
\text { Tanah dengan } 15 \% \\
\text { Abu Ampas Tebu } \\
\text { Dan Abu Arang } \\
\text { Kelapa }\end{array}$} & - Berat Cetakan & 4500 & 4500 & 4500 & 4500 \\
\hline & - Berat Tanah Basah + Cetakan & 6253 & 6055 & 6181 & 6221 \\
\hline & - Berat Tanah Basah (W) & 1753 & 1555 & 1681 & 1721 \\
\hline & - Berat Tanah Kering Oven (Ws) & 1537 & 1534 & 1611 & 1665 \\
\hline & - Berat Air $(\mathrm{Ww})=\mathrm{W}-\mathrm{Ws}$ & 216 & 21 & 70 & 56 \\
\hline & - $(\mathrm{Wc})=\mathrm{Ww} / \mathrm{Ws}^{*} 100(\%)$ & 14.05 & 1.37 & 4.35 & 3.36 \\
\hline & - Isi Cetakan $(\mathrm{V})=\Pi \cdot \mathrm{R}^{2} . \mathrm{T}$ & 188.28 & 188.28 & 188.28 & 188.28 \\
\hline & - Berat Volume $(\mathrm{Y}$ sat $)=\mathrm{W} / \mathrm{V}$ & 9.31 & 8.26 & 8.93 & 9.14 \\
\hline & - Berat Volume Kering $(\mathrm{Vd})=\mathrm{Ws} / \mathrm{V}$ & 8.16 & 8.15 & 8.56 & 8.84 \\
\hline
\end{tabular}

Sumber : Hasil Analisis Uji Proctor di Laboratorium Teknik Sipil Universitas Kadiri. 
Pada Gambar 7. merupakan hasil Uji proctor mix tanah $15 \%$ abu ampas tebu dan abu batok kelapa menunjukkan bahwa berat volume kering ialah 10,10 gram dengan kadar air $4,35 \%$.

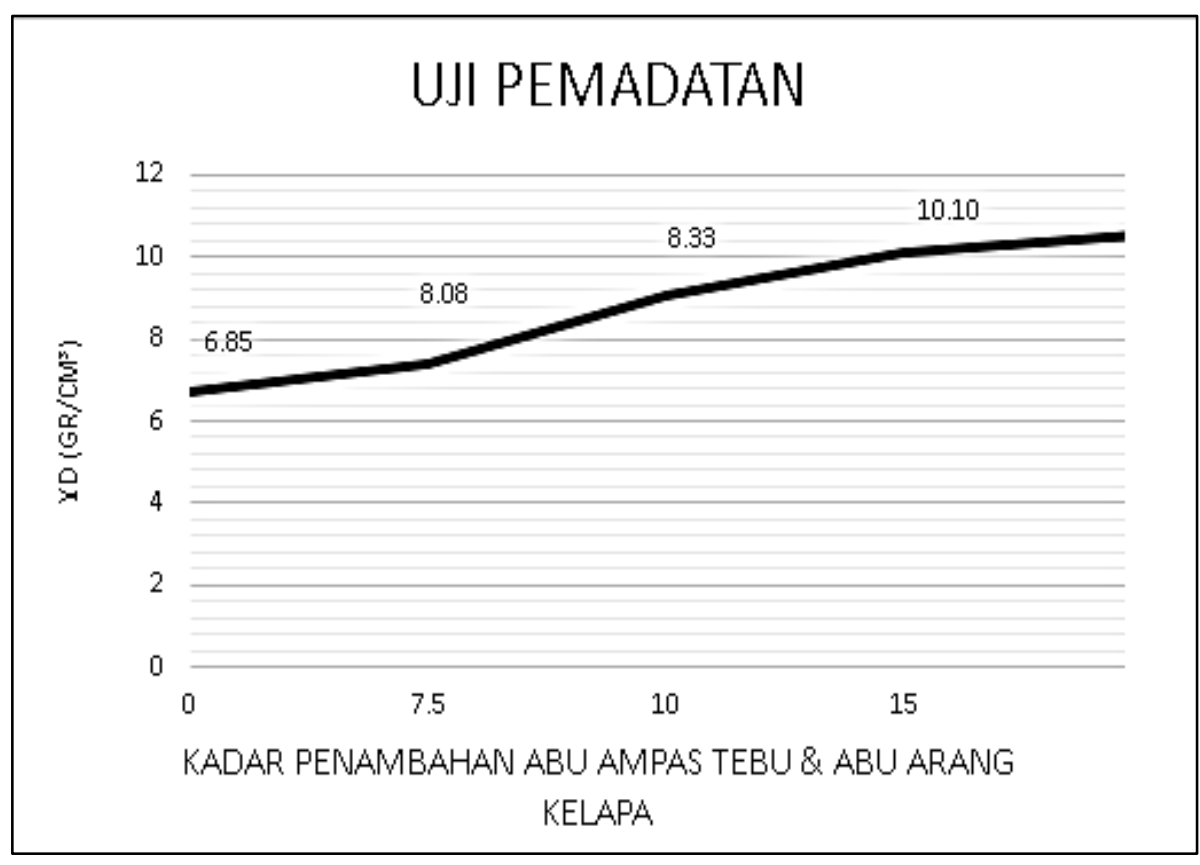

Sumber : Hasil Analisis Uji Proctor Keseluruhan Benda.

Gambar 7. Grafik Hasil Uji Kepadatan Tanah dari Keseluruhan Benda Uji.

Dengan berikut disimpulkan bahwa semakin besar persentase penambahan abu ampas tebu \& abu arang kelapa, berat volume kering suatu benda uji mengalami penurunan berat secara berturut-turut. Penambahan air sebesar $10 \%$ penambahan abu ampas tebu $\&$ arang batok kelapa sebanyak 0\% sebesar 6,85 gr/ $\mathrm{cm}^{3}$. penambahanAbu Ampas Tebu \& Abu Arang Kelapa sebanyak $7 \%$ berat volume kering $8,08 \mathrm{gr} / \mathrm{cm}^{3}, 10 \%$ adalah $8,33 \mathrm{gr} / \mathrm{cm}^{3}, 15 \%$ adalah 10,10 $\mathrm{gr} / \mathrm{cm}^{3}$.

\section{KESIMPULAN}

Dari hasil penelitian mengenai pengaruh penambahan abu ampas tebu dan arang batok kelapa terhadap stabilisasi daya dukung tanah yang telah dilakukan, dapat diambil kesimpulan sebagai berikut :

1. Pada Nilai $0 \%$ pada struktur tanah asli didapat nilai Liquid Limit $57 \%$, Platic Limit $24,25 \%$, Index Plastic 32,75 \%. Pada penambahan $7 \%$ didapat nilai Liquid limit menjadi $50 \%$, Plastic Limit 26,30, Index Plastic 23,70 \%, pada penambahan $10 \%$ didapat nilai Liquid Limit menjadi $49 \%$, Plastic Limit 29,75\%, Index Plastic 19,25\% dan penambahan sebesar $15 \%$ didapat nilai Liquid Limit 39 \%, Plastic Limit 28,38\%, Index Plastic $10,62 \%$. 
2. Pengujian batas konsistensi struktur tanah menunjukkan bahwa, penambahan abu ampas tebu dan arang batok kelapa berpengaruh terhadap stabilitas tanah. Semakin besar prosentase penambahan ampas tebu dan arang batok kelapa, nilai liquid limit, plastic limit, dan index plastic akan mengalami penurunan sehingga dapat disimpulkan bahwa tingkat keplastisan tanah semakin kecil seiring dengan ditingkatkannya prosentase abu ampas tebu dan arang batok kelapa.

\section{SARAN}

Saran terhadap penelitian ini adalah untuk mengetahui efektif atau tidaknya campuran abu ampas tebu dan arang batok kelapa perlu diteliti lebih lanjut sehingga akan diketahui nilai nyata terjadinya perubahan akibat pengaruh penambahaan bahan tersebut.

\section{UCAPAN TERIMAKASIH}

Dengan ini saya sampaikan kepada Bapak. Sigit Winarto selaku Dosen Pembimbing I, Bapak Dr.Ahmad Ridwan selaku Dosen Pembimbing II, Bapak Yosef Cahyo selaku Dekan, Bapak Eko Siswanto selaku kajur dan Suami, Bapak Ibu orang tua beserta seluruh keluarga yang selalu mendo'akan dan mendukung dalam banyak hal. 


\section{DAFTAR PUSTAKA}

[1] A. I. Candra, S. Anam, Z. B. Mahardana, and A. D. Cahyono, "STUDI KASUS STABILITAS STRUKTUR TANAH LEMPUNG PADA JALAN TOTOK KEROT KEDIRI MENGGUNAKAN LIMBAH KERTAS,” Ukarst J. Univ. Kadiri Ris. Tek. Sipil, vol. 2, no. 2, pp. 88-97, 2018.

[2] S. B. Azzyzaro Junior Karaseran, Oktovian B. A. Sompie, "PENGARUH BAHAN CAMPURAN ARANG TEMPURUNG TERHADAP KONSOLIDASI SEKUNDER PADA LEMPUNG EKSPANSIF,” J. Sipil Statik, vol. 3, no. 8, pp. 544-547, 2015.

[3] F. Febriantoro, Y. C. S. P, and A. R. A, "STUDY PERENCANAAN PONDASI TIANG PANCANG JEMBATAN SEMBAYAT BARU II KECAMATAN MANYAR, KABUPATEN GRESIK," Jurmateks, vol. 1, no. 1, pp. 148-159, 2018.

[4] Martini, "Pengaruh Tingkat Kepadatan Tanah Terhadap Daya Dukung Tanah," SMARTek, vol. 7, no. 2, pp. 69-81, 2009.

[5] Bowless J, "Sifat sifat Fisis dan Geoteknis Tanah,” Jakarta:Erlangga, 1984. .

[6] A. I. Candra, "ANALISIS DAYA DUKUNG PONDASI STRAUSS PILE PADA PEMBANGUNAN GEDUNG MINI HOSPITAL UNIVERSITAS KADIRI," Ukarst, vol. 1, no. 1, pp. 63-70, 2017.

[7] Das Braja M, Mekanika Tanah (Prinsip-prinsip Rekayasa Geoteknis), 1st ed. Erlangga, 1995.

[8] L. Sintyawati, S. Winarto, A. Ridwan, and A. I. Candra, "STUDI PERENCANAAN STRUKTUR PONDASI TIANG PANCANG GEDUNG FAKULTAS SYARIAH IAIN PONOROGO,” Jurmateks, vol. 1, no. 2, pp. 227-237, 2018.

[9] Dr.Ir.Lusmeilia Afriani, "Kuat Geser Tanah Pengertian Bentuk Istilah Tanah,” 2014.

[10] B. Efendi Situmorang and M. Ardan, "Pengaruh Waktu Pemeraman Dengan Penambahan Kapur Sebagai Bahan Additve Pada Tanah Lempung Ekspansif Terhadap Nilai CBR Tanah," J. Civ. Eng. Build. Transp., vol. 3, no. 2, p. 97, 2019, doi: 10.31289/jcebt.v3i2.2779.

[11] R. I. Kurniawan, A. Ridwan, S. Winarto, and A. I. Candra, "PERENCANAAN PONDASI TIANG ( Studi Kasus HOTEL MERDEKA TULUNGAGUNG )," Jurmateks, vol. 2, no. 1, pp. 144-153, 2019.

[12] Terzaghi, Mekanika Tanah Dalam Praktek Rekayasa. 1987. 
[13] B. A. Wiratmoko, S. Winarto, and Y. C. S. P, "PERENCANAAN PONDASI TIANG PANCANG GEDUNG KETAHANAN PANGAN NGANJUK,” Jurmateks, vol. 2, no. 1, pp. 106-120, 2019.

[14] Q. Wiqoyah, "Pengaruh Kadar Kapur, Waktu Perawatan dan Perendaman Terhadap Kuat Dukung Tanah Lempung,” Din. Tek. Sipil, vol. 6, no. 1, pp. 16-24, 2006.

[15] A. A. Destamara, "PENGARUH PENAMBAHAN ABU AMPAS TEBU TERHADAP KARAKTERISTIK TANAH LEMPUNG EKSPANSIF DI BOJONEGORO,” J. Chem. Inf. Model., vol. 53, no. 9, pp. 1-9, 2013, doi: 10.1017/CBO9781107415324.004.

[16] J. D. Pangouw, R. Pandaleke, and J. B. Mangare, "Substitusi Parsial Semen Dalam Campuran Beton Ditinjau Terhadap Kuat Tarik Lentur Dan Modulus Elastisitas,” J. Sipil Statik, vol. 1, no. 2, pp. 82-89, 2013.

[17] I. Baskara, I. Aribudiman, and A. Tjerita, "Pengaruh Penambahan Fiber Terhadap Parameter Daya Dukung Tanah Lempung,” J. Ilm. Tek. Sipil, vol. 19, no. 1, pp. 1-9, 2015.

[18] F. Ferdian and M. Jafri, "Pengaruh Penambahan Pasir Terhadap Tingkat Kepadatan dan Daya Dukung Tanah Lempung Organik,” Jrsdd, vol. 3, no. 1, pp. 145-156, 2015.

[19] A. Hakam, R. Yuliet, and R. Donal, "Studi Pengaruh Penambahan Tanah Lempung Pada Tanah Pasir Pantai Terhadap Kekuatan Geser Tanah,” J. Rekayasa Sipil, vol. 6, no. 1, p. 11, 2010, doi: 10.25077/jrs.6.1.11-22.2010.

[20] B. P. Andreas Gunarso, Rizqi Nurprayogi, Windu Partono, "Stabilisasi Tanah Lempung Ekspansif Dengan Campuran Larutan NaOH 7,5 \%," Karya Tek. Sipil, vol. 6, no. 2, p. $240,2017$.

[21] Joseph E, “Sifat-sifat Fisis dan Geoteknis Tanah,” Jakarta: Erlangga.

[22] A. T. Sudjianto, "STABILISASI TANAH LEMPUNG EKSPANSIF DENGAN GARAM DAPUR ( $\mathrm{NaCl}$ ),” Tek. Sipil, 2007.

[23] Anita Setyowati Srie Gunarti, "Daya Dukung Tanah Lempung yang Distabilisasi dengan Spent Catalyst Rcc dan Kapur," Bentang, vol. 2, no. 1, pp. 38-52, 2014. 